\title{
FIZJOLOGIA I ROZRODCZOŚĆ KOBIETY W PISMACH METODEGO Z OLIMPU I AMBROŻEGO Z MEDIOLANU
}

Refleksja Ojców Kościoła na temat kobiet dotyczyła najczęściej zagadnień duchowych i religijnych. Rzadko natomiast podejmowali oni kwestie związane z żeńską fizjologią i różnymi aspektami rozrodczości. W znacznej mierze powielali wtedy zarówno terminologię, jak i przekonania ówczesnej medycyny $^{1}$, a ich wypowiedzi służyły określonym celom teologicznym, moralnym i duszpasterskim. Autorzy kościelni IV-V w. wskazywali na dwie podstawowe kobiece role: żony-matki i dziewicy. Szacunkiem otaczano także stan wdowi, polegający na świadomym wyborze życia w permanentnej czystości po śmierci pierwszego małżonka² ${ }^{2}$ Osobną kategorię stanowił ideał dziewicy-męczennicy.

Celem niniejszego artykułu jest przybliżenie wczesnochrześcijańskich poglądów i wyobrażeń na temat rozrodczości i fizjologii kobiecej na podstawie dzieł Metodego z Olimpu († 311) i Ambrożego z Mediolanu († 397). Wybór tych dwu autorów, pochodzących z różnych epok i środowisk kulturowych, podyktowany jest kilkoma czynnikami. Po pierwsze obydwaj odznaczali się daleko posuniętą znajomością zagadnień medycznych. Po drugie, pozytywnie oceniali małżeństwo i samą płciowość, pomimo pierwszeństwa przypisywanego czystości i dziewiczej formie życia, której opisowi poświęcili specjalne dzieła. Wreszcie, zestawienie poglądów tych dwu autorów, pozwoli uchwycić swoistą metodę pisarzy kościelnych, którzy starali się wykorzystać elementy wiedzy medycznej do wyjaśnienia zagadnień teologicznych i realizacji celów duszpasterskich. W artykule wskazane zostaną używane przez wymienionych autorów pojęcia związane z płodnością oraz przeanalizowane podstawy biblijne i cele teologiczne ich wypowiedzi. Porównanie z poglądami starożytnych

* Dr Mirosław Mejzner SAC - adiunkt w Katedrze Teologii Patrystycznej w Instytucie Teologii Systematycznej na Wydziale Teologicznym Uniwersytetu Kard. Stefana Wyszyńskiego w Warszawie; e-mail: m.mejzner@uksw.edu.pl.

${ }^{1} \mathrm{~W}$ starożytności istniały specjalne traktaty medyczne poświęcone nie tylko kobietom w ogólności, ale także szczegółowym kwestiom ginekologicznym. Obok odnośnej części Corpus Hippo-

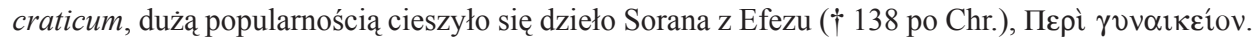
Na opinie Ojców Kościoła w tej dziedzinie ogromny wpływ wywarły ponadto poglądy Arystotelesa.

${ }^{2}$ Por. C. Mazzucco, Matrimonio e verginità nei Padri tra IV e V secolo: prospettive femminili, w: La donna nel pensiero cristiano antico, ed. U. Mattioli, Genova 1992, 119. 
filozofów i medyków ukaże w jaki sposób kontekst epoki wpłynął na wczesnochrześcijańską egzegezę i ukształtowanie się określonych poglądów teologicznych i społecznych. Choć zatem temat artykułu może wydawać się błahy, to jednak z historycznego punktu widzenia, jest niezwykle ciekawy.

\section{STAROŻYTNE POGLĄDY FILOZOFICZNO-MEDYCZNE O ROZRODCZOŚCI}

Poglądy starożytnych lekarzy i filozofów greckich legły u podstaw wyobrażeń Ojców Kościoła na temat fizjologii i rozrodczości. Dlatego warto, choćby syntetycznie, wskazać funkcjonujące wtedy idee na temat płodności ${ }^{3}$. Wpływ na nie miały nie tylko anatomiczne badania organizmów, ograniczone z powodu braku wiedzy na temat komórek, ale także pewne założenia społeczne, wyrażające się w nierównej ocenie obydwu płci. Zasadniczo w starożytnej myśli greckiej można wyróżnić cztery stanowiska, związane z określonymi etapami refleksji filozoficzno-medycznej ${ }^{4}$.

1. Koncepcja kobiety jako ziemi przyjmującej ziarno. Sposób poczęcia i prenatalny rozwój dziecka były porównywane często do uprawy zboża. W optyce tej rolniczej metafory, kobieta uosabia ziemię, przyjmującą zasiane przez mężczyznę ziarno, będące początkiem życia, by je odżywić i ostatecznie wydać na świat. Porównanie to zawierało w sobie dwa przekonania. $Z$ jednej strony ukazywało pierwszeństwo mężczyzny w prokreacji i jego prawo do potomstwa, z drugiej uwypuklało tajemniczą siłę kobiety, która warunkuje wzrost nasienia, ale jest również w stanie zniszczyć w sobie owoc męskiej potencji. Takie przekonanie wyraził np. Ajschylos († 456 prz. Chr.) w jednym ze swoich dramatów:

„Nie płodzi matka tego, co się zowie płodem, / a jeno żywi w łonie swym zasiane ziarno. / Płodzi ten, kto zapładnia; ona przechowuje / wiernie skarb powierzony, jeśli go nie zniszczy / wola boża"s.

Teoria „pojedynczego nasienia” miała swoich zwolenników także wśród filozofów. Anaksagoras († 428 prz. Chr.), na bazie filozoficznego założenia, że byt nie może pochodzić od niebytu, głosił zarodkową teorię przyrody. Konsekwencją tej teorii była teza, iż w nasieniu męskim zawarty jest już każdy element ciała (kości, żyły, nerwy, organy, a nawet włosy i paznokcie). Z kolei

${ }^{3}$ Szerzej na temat starożytnej rozrodczości i „embriologii” por. L. Cilliers, Vindicianus' Gynaecia and theories on generation and embryology from the Babylonians up to Graeco-Roman times, „Studies in Ancient Medicine” 27 (2004) 343-367; M.-H. Congourdeau, L'embryon et son âme dans les sources grecques, Paris 2007.

${ }^{4}$ Por. E. Prinzivalli, Donna e generazione nei Padri della Chiesa, w: La donna nel pensiero cristiano antico, s. 79-82.

${ }^{5}$ Aeschylus, Eumenides, w. 656-660, ed. P. Mazon, w: Eschyle, Opera, t. 2, Paris 1961, 157, thum. S. Srebrny: Ajschylos, Eumenidy, w: Ajschylos, Tragedie, Warszawa 1954, 471. 
Diogenes z Apolonii (V w. prz. Chr.) twierdził, że choć w spermie znajduje się całość nowego życia, to jednak do rozwoju nasienia potrzebne jest odpowiednie ciepło, które mężczyzna przekazuje kobiecie podczas stosunku6.

2. Koncepcja „dwóch ziaren”. Filozofowie greccy już w V w. prz. Chr. zastanawiali się nad istnieniem jakiegoś rodzaju „ziarna” żeńskiego, które w sposób aktywny uczestniczyłoby w tworzeniu embrionu. Punktem wyjścia ich refleksji był najprawdopodobniej fakt podobieństwa potomstwa do matki. Brak możliwości obserwacji komórek i eksperymentalnej weryfikacji tej hipotezy nie doprowadził do jej triumfu, pomimo jej popularności ${ }^{7}$. Hipokrates († 370 prz. Chr.) próbował potwierdzić ją empirycznie. W jego środowisku pojawiła się nawet hipoteza, że u obu płci występuje równocześnie nasienie męskie i żeńskie ${ }^{8}$.

W De genitura wyjaśniał, że momentem „zasiania” tak męskiego, jak i żeńskiego ziarna jest stan orgazmu? $\mathrm{U}$ mężczyzn następuje on w wyniku podrażnienia części genitalnych, co prowadzi do spienienia się w organizmie płynów pochodzących ze wszystkich części ciała. Piana ta gromadzi się następnie w mózgu, skąd kręgosłupem zostaje przetransportowana do lędźwi, a z nich do jąder, by w procesie ejakulacji wydostać się na zewnątrz. Analogiczny proces u kobiety ogniskuje się natomiast w macicy. Różny stopień podobieństwa do jednego z rodziców Hipokrates wyjaśniał ilością ziarna pochodzącego od ojca i matki.

W II w. po Chr., wbrew rozpowszechnionym wówczas poglądom Arystotelesa, do teorii dwóch ziaren powrócił pochodzący z Pergamonu rzymski lekarz Galen († ok. 200 po Chr.). Była ona dla niego jedynym możliwym wytłumaczeniem podobieństwa dzieci do obojga rodziców. Jego zdaniem męskie nasienie, choć bardziej aktywne od żeńskiego, oprócz energii przynosi także materię ${ }^{10}$.

Teoria dwóch ziaren zakładała aktywną rolę kobiety w procesie prokreacyjnym. Jej popularność nie doprowadziła jednak do jakiejś głębszej refleksji filozoficznej na temat równości kobiety i mężczyzny.

3. Embriologia jako pochodna założeń metafizycznych i społecznych. Myślicielem, którego teorie na długie wieki zaważyły na rozumieniu prokreacji, był Arystoteles († 322 prz. Chr.). Pomimo obserwacji empirycznych i sekcji przeprowadzanych na zwierzętach, jego poglądy odzwierciedlają nie

\footnotetext{
${ }^{6}$ Por. A. Muszala, Embrion ludzki w starożytnej refleksji teologicznej, Kraków 2009, 30-35.

${ }^{7}$ Takie poglądy mieli np.: Anaksagoras, Parmenides, Empedokles, Demokryt, a później Epikur, a nawet - przynajmniej na pewnym etapie - Platon (Timaeus 91a-d). Por. A. Tosato, Processo generativo e sangue nell'antichità, w: Sangue e antropologia nella letteratura cristiana (Roma, 29 novembre - 4 dicembre 1982), ed. F. Vattioni, t. 2, Roma 1983, 685-690.

${ }^{8}$ Por. Hippocrates, De genitura VI 1-2.

${ }^{9}$ Por. tamże IV 1.

${ }^{10}$ Por. Galenus, De semine I 2; II 2.
} 
tylko założenia metafizyczne, ale także kluczowe starożytne idee społeczne, w tym tę o wyższości mężczyzny nad kobietą. Ogólne ramy teorii Arystotelesa stanowia zasady jego metafizyki. W kwestiach fizjologicznych natomiast podstawą jego rozważań było uznanie ciepła za kluczowy czynnik kierujący procesem trawienia pokarmu i budowy organizmu. Porównywał ten proces do gotowania, podczas którego z dostarczonych produktów wytwarzane są odpowiednie rodzaje krwi, która z kolei odżywia poszczególne organy i przyczynia się do ich wzrostu.

Sperma to - według niego - najbardziej wysublimowany produkt powstały z krwi w wyniku skomplikowanego procesu metabolicznego ${ }^{11}$. Podczas ejakulacji jest ona biała i zagęszczona. Gęstość zależy od obecnej w niej pneumy, tj. gorącego powietrza, a biel od struktury piany. Do produkcji spermy potrzeba szczególnie dużo ciepła. Dlatego może się ona dokonać jedynie w dojrzałym i zdrowym organizmie mężczyzny. Chory, starzec i chłopiec nie produkuja jej. Podobnie kobieta, jako istota chłodna i wilgotna, nie posiada wystarczającej ilości energii do jej wytworzenia. Jej krew menstruacyjna jest materiałem podobnym do tworzywa spermy, ale nie przetworzonym przez ciepło. Ani spermy, ani krwi menstruacyjnej Arystoteles nie uważał jednak za materiały (nasienie) w znaczeniu genetycznym, ale jedynie za ciecze rozrodcze ( $\gamma \circ v \eta ́)$. Podkreślał, że dopiero ich zmieszanie podczas stosunku wywołuje określone skutki. Energia zawarta w spermie prowadzi do przekształcenia w mleko gromadzące się w piersiach, nadmiaru krwi, która w zwyczajnych warunkach jest wydalana $\mathrm{w}$ postaci menstruacji ${ }^{12}$. Jako podstawowy owoc stosunku wskazywał oczywiście powstanie właściwego nasienia, z którego rozwija się embrion. Arystoteles twierdził, że sperma, oddziałując na krew menstruacyjna, w podobny sposób jak podpuszczka na mleko, prowadzi do jej zagęszczenia ${ }^{13}$. Ponieważ przenosi ona także element witalny i formalny (anima) jest przyczyną animacji płodu (po około 40 dniach w przypadku chłopców i po 90 dniach w przypadku dziewczynek).

Arystoteles uważał, że do powstania embrionu kobieta dostarcza materii, a mężczyzna aktywnego czynnika, który ją przekształca i formuje. Taki pogląd był pochodną jego metafizyki, opartej na rozróżnianiu w bycie materii i formy. W tej optyce rola mężczyzny została szczególnie dowartościowana, gdyż produkowana przez niego sperma została uznana za czynnik ruchu, przyczynę sprawczą, formalną i celową ludzkiego płodu. I to właśnie dzięki wspaniałości

${ }^{11}$ Por. Aristoteles, De generatione animalium $725 \mathrm{a} ; 726 \mathrm{~b}$. W starożytności istniały zasadniczo trzy teorie dotyczące powstawania męskiego nasienia: mielogenetyczna (z mózgu i rdzenia), pangenetyczna (ze wszystkich tkanek), hemogenetyczna (ze spienionej krwi). Zob. Muszala, Embrion ludzki, s. 70-72.

${ }^{12}$ Por. Aristoteles, De generatione animalium 776a-777a.

${ }^{13} \mathrm{~W}$ starożytnej Grecji do ścinania mleka używano kwasu figowego. Arystoteles (De generatione animalium 729a; 739b; tenże, Historia animalium 522b) wykorzystał ten proces do wytłumaczenia działania spermy na krew menstruacyjną. 
tej funkcji, natura - według Arystotelesa - odróżniła mężczyzn od kobiet, czyli rzeczywistość wyższą od niższej ${ }^{14}$.

Autorytet Arystotelesa sprawił, że jego teorie cieszyły się powszechnym uznaniem przez wiele wieków. Porzucono je dopiero w czasach nowożytnych. Pomimo oczywistych założeń ideologicznych, należy podkreślić wyjątkową siłę perswazyjną jego argumentacji. Potrafił bowiem stworzyć spójną teorię, która nie tylko wyjaśniała sposób powstawania płodu, ale także naturę krwi menstruacyjnej, rozumianej jako źródło pożywienia, oraz przyczynę tworzenia się mleka kobiecego z tej krwi, w wyniku transformacji wymagającej dużo mniejszej energii niż produkcja spermy.

4. Sperma jako nośnik życia fizyczno-duchowego. Czwarte stanowisko było wynikiem wpływu teorii Arystotelesa na poglądy stoików. Konstytutywnym elementem ich filozofii była idea pneumy. Twierdzili, że cały makroi mikrokosmos jest przeniknięty tą siłą życiowa, będącą najsubtelniejszą materią o ognistej naturze. Według nich, to właśnie pneuma zawarta w spermie, będącej esencją siły, tworzy i organizuje embrion, przekazując mu najpierw życie wegetatywne, a w potencji także rozumne. Samą spermę uznawali za nośnik cech dziedzicznych przodków, co można uznać za genialną intuicję genetyczną. Przypisanie jedynie mężczyźnie aktywnej roli i połączenie spermy z pneuma, prowadziło do pomniejszania czy wręcz przekreślenia aktywnej i genetycznej roli kobiety w prokreacji. Stoicy odrzucali pogląd o istnieniu żeńskiego nasienia, chociaż Zenon z Kition († 263 prz. Chr.), według świadectwa Euzebiusza z Cezarei, rozważał współudział duszy kobiety w powstaniu pneumy w płodzie ludzkim ${ }^{15}$. Ten pneumatyczny element miałby się łączyć w macicy z nasieniem męskim tworząc embrion. Punktem wyjścia tych rozważań była znów próba wyjaśnienia przyczyn podobieństwa dziecka do matki.

\section{WCZESNOCHRZEŚCIJAŃSKA WIZJA PŁODNOŚCI I ROZRODCZOŚCI}

Tematyka życia małżeńskiego i rodzinnego zajmuje pokaźne miejsce w twórczości patrystycznej. Jest to zrozumiałe, zważywszy na jej znaczenie tak dla życia społecznego, jak i eklezjalnego. W Kościele pierwotnym kobiety odgrywały bardzo ważną rolę i cieszyły się daleko posuniętą emancypacją, dużo większą niż w życiu cywilnym. Jednak obawa przed potencjalnie rewolucyjnymi zmianami w strukturach kościelnych wpłynęła na pomniejszenie ich znaczenia i ograniczenie powierzanych im funkcji, co w konsekwencji doprowadziło do upodobnienia organizacji wspólnot eklezjalnych do modeli funkcjonujących wówczas w świecie żydowskim i rzymskim ${ }^{16}$.

\footnotetext{
${ }^{14}$ Por. tenże, De generatione animalium 729a; 732a.

${ }^{15}$ Por. Eusebius, Praeparatio evangelica XV 20, 1 (= Stoicorum veterum fragmenta I 128).

${ }^{16}$ Por. M. Simonetti, Presentazione, w: La donna nel pensiero cristiano antico, s. 7.
} 
Choć pisarze wczesnochrześcijańscy nie pozostawili po sobie specjalnych traktatów poświęconych moralności seksualnej, to jednak ich liczne zachęty do życia dziewiczego i czystości wpłynęły znacząco na sposób patrzenia na płciowość. Podstawę biblijną ich poglądów stanowiły słowa Jezusa (Mt 19, 3-6), który z jednej strony potwierdził godność aktu małżeńskiego jako odwieczny zamysł Boga, z drugiej, wprowadzając kategorię „bezżennych dla Królestwa Niebieskiego", otworzył drogę do przewartościowania odniesień do seksualności. Na szczycie chrześcijańskiej hierarchii aksjologicznej znalazły się czystość i dziewictwo, wyniesione ponad wartość życia małżeńskiego. Zwolennikiem takich poglądów był już św. Paweł, który propagował wśród chrześcijan osobiście praktykowany ideał życia dziewiczego, a małżeństwo definiował jako środek zaradczy na rozpustę i pożądliwość ciała (por. 1Kor 6, 12-20). Pomimo narastającej podejrzliwości wobec seksualności, autorzy kościelni nie oceniali małżeństwa negatywnie, co odróżnia ich jednoznacznie od potępiających cielesność ruchów heretyckich, takich jak: doketyzm, enkratyzm, montanizm, manicheizm. Pomimo tak wyraźnej cezury, w pismach niektórych autorytetów kościelnych można znaleźć sugestie o istnieniu jakiegoś związku pomiędzy płciowością i upadkiem pierwszych rodziców. Wpłynęło to niewaţpliwie na pogłębianie podejrzliwości wobec niej, a nawet obarczenie jej piętnem grzeszności. Wymownym świadectwem walki z rzeczywistością erosa jest łacińska literatura ascetyczno-monastyczna, w której pożądliwość cielesna jest często oceniana jako zło, polegające na dominacji ciała nad rozumem i pierwotną harmonią ${ }^{17}$. Pomimo wyższości przypisywanej czystości, także w ramach małżeństwa, można jednak znaleźć w pismach Ojców Kościoła passusy oceniające $\mathrm{w}$ sposób pozytywny siłę pociągu erotycznego ${ }^{18}$, słodycz intymności, bliskość cielesną i zjednoczenie pierwszej nocy ${ }^{19}$, upajanie się wymianą spojrzeń, uśmiechów, słów ${ }^{20}$ etc.

Na refleksję wczesnochrześcijańską dotyczącą biologicznej i fizjologicznej strony rozrodczości ogromny wpływ wywarły poglądy Arystotelesa i stoików, które poprzez Warrona († 27 prz. Chr.) dotarły do Rzymu. Przyjmowano zasadniczo, że w procesie rozrodczym kobieta odgrywa pasywną rolę (jak ziemia dla nasienia lub inkubator). Takie założenie legło u podstaw wielu rozważań teologicznych, zwłaszcza tych dotyczących natury poczęcia i narodzin Syna Bożego. Nie chodziło oczywiście o przypisanie Bogu Ojcu fizycznej roli, jaką podczas prokreacji pełni mężczyzna, ale o uznanie w Nim jedynego aktywnego podmiotu. Być może daleką aluzję do takiego sposobu

${ }^{17}$ Por. S. Pricoco, Introduzione, w: L'eros difficile. Amore e sessualità nell'antico cristianesimo, ed. S. Pricoco, Armarium 9, Soveria Mannelli 1998, 9-11.

${ }^{18}$ Por. Joannes Chrysostomus, In epistulam I ad Corinthios hom. 23, 5; tenże, In epistulam ad Ephesios hom. 20, 1.

${ }^{19}$ Por. tenże, De non iterando coniugio 4.

${ }^{20}$ Por. Gregorius Nazianzenus, Carmen I 2, 29, 91-92; Joannes Chrysostomus, De non iterando coniugio 2. 
poczęcia można odczytać w J 1, 14. Natomiast materialność Chrystusa wiązano całkowicie z Maryją. Ignacy z Antiochii $(\dagger 107)$ pisał o Bogu w człowieku, pochodzącym według ciała z rodu Dawida, Synu Bożym, który prawdziwie narodził się z Dziewicy Maryi i z Boga ${ }^{21}$. Arystydes († 134) wyjaśniał, że Syn

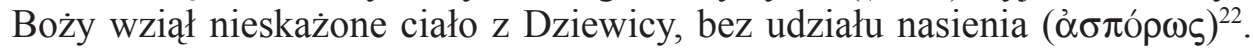
Tertulian († po 222), polemizując $z$ antropologią doketów, podkreślał całkowitą prawdziwość ciała Chrystusa, zapewniona przez przyjęcie ciała w Maryi. Jednocześnie wyjaśniał, że Syn Boży został zrodzony „,z nasienia Boga Ojca, którym jest Duch"23. W ten nurt wpisują się też, przy całej ich oryginalności, poglądy Metodego z Olimpu i Ambrożego z Mediolanu.

1. Metody z Olimpu. Dziesięć dziewic, debatujących w ogrodzie Cnoty i prześcigających się w laudacjach na temat czystości, to bohaterki Symposium, jedynego zachowanego w całości w greckim oryginale dzieła Metodego $^{24}$. Powierzenie kobietom funkcji wyrażenia bogactwa i szerokiego spektrum chrześcijańskiego ideału wydaje się nieprzypadkowe. Prawdopodobnie nie chodzi jedynie o literacką fikcję. Dzieło Metodego jest być może jednym z najwcześniejszych świadków istnienia żeńskich środowisk ascetycznych w Azji Mniejszej, jeszcze przed ukształtowaniem się właściwej formy monastycyzmu ${ }^{25}$. Innym przykładem ważnej figury żeńskiej w jego dziełach jest cnotliwa kobieta z Licji, filozofka i nauczycielka słowa Pańskiego ${ }^{26}$. Jej prototypem mogła być św. Tekla, której małoazjatycki kult rozwijał się żywiołowo. Jego wyrazem jest z pewnością ósma mowa w Symposium i końcowy hymn na cześć dziewictwa wygłoszony przez zwyciężczynię agonu, właśnie o imieniu Tekla. Jeżeli żeńskie środowiska ascetyczne rzeczywiście już wtedy istniały, to Metody miał z nimi najprawdopodobniej bliski kontakt. Tematyka kobiet nie była mu zatem obca. Wśród wielu jego refleksji pojawiają się m.in. tematy związane z rozrodczością.

a) Etiologia menstruacji. Zagadnienie menstruacji pojawia się niespodziewanie w trakcie argumentacji Metodego dotyczącej zmartwychwstania ciała. Skąd taka, zdawać by się mogło czysto fizjologiczna tematyka podczas

${ }^{21}$ Por. Ignatius Antiochenus, Ad Ephesios VII 2; tenże, Ad Smyrnaeos I 1.

${ }^{22}$ Por. Aristides, Apologia 15, 1, ed. B. Pouderon - M.-J. Pierre, SCh 470, 286, Paris 2003, 286.

${ }^{23}$ Tertullianus, De carne Christi XVIII 1, ed. J.P. Mahé, SCh 216, Paris 1975, 282: „dei filius ex patris dei semine, id est spiritus", thum. własne.

${ }^{24}$ Methodius, Symposium, ed. H.A. Musurillo - V.H. Debidour, SCh 95, Paris 1963, thum. S. Kalinkowski: Metody z Olimpu, Uczta, w: Pierwsze pisma greckie o dziewictwie, ŹM 16, Tyniec - Kraków 1997, 127-253.

${ }^{25}$ Podczas sympozjum metodiańskiego w Jenie (por. M. Mejzner - F. Candido, [Relacja z sympozjum] Metody z Olimpu: stan badań i perspektywy [Jena, Uniwersytet Fryderyka Schillera, 19-22 II 2015], VoxP 36 (2016) t. 66, 655-659, Federica Candido przedstawiła nowe argumenty dla poparcia tej hipotezy, wysuwanej już kilkakrotnie przez innych badaczy (H.A. Musurillo, L.G. Patterson, E. Prinzivalli).

${ }^{26}$ Por. Methodius, De lepra XIII. 
ważkich teologicznie rozważań? Otóż na początku IV w. dylemat rezurekcyjny ogniskował się nie tyle na kwestiach teologicznych i chrystologicznych, ale na antropologicznych, a w szczególności na rozumieniu natury ciała. Autorzy starali się znaleźć spójną i zasadną odpowiedź na fundamentalne pytanie: co zmartwychwstanie?; albo bardziej precyzyjnie: jaka będzie relacja między ciałem składanym do grobu i ciałem zmartwychwstałym? ${ }^{27}$

W kręgach kościelnych, odrzucających wszelkiego rodzaju poglądy gnostyckie i platonizujące, rozumiano zmartwychwstanie jako przywrócenie do życia tego samego ciała, choć oczywiście przemienionego na wzór zmartwychwstałego ciała Chrystusa, a więc duchowego, nieśmiertelnego i niezniszczalnego. Nie mogło to być jednak inne ciało. W rozumieniu autorów starożytnych musiało być więc złożone $\mathrm{z}$ tych samych elementów materialnych.

Takiemu rozumieniu zmartwychwstania zdecydowanie przeciwstawił się Orygenes, który podkreślał nieustanną zmienność elementów tworzących substrat materialny ciała. Dynamikę odżywiania ciała porównywał do nieustannie płynącej rzeki, która nigdy nie jest taka sama. Jego interesująca koncepcja,

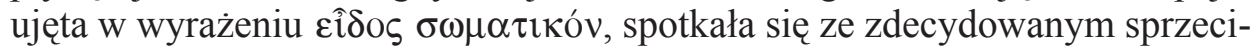
wem, gdyż odbiegała znacząco od tradycyjnego rozumienia dogmatu i przez nieokreśloność dotyczącą aspektu materialności ciała mogła się wydawać za zbyt zbieżną z poglądami gnostyków.

Jako pierwszy polemikę z poglądami Aleksandryjczyka i szerokim frontem platonizujących chrześcijan podjął Metody z Olimpu. W dialogu $O$ zmartwychwstaniu ${ }^{28}$ starał się m.in. dowieść istnienia elementów konstytutywnych ciała, to znaczy takich, które trwają w nim nieprzerwanie przez całe życie. Według niego ciało to zbiór elementów konstytutywnych (należących do czterech podstawowych substancji: ziemi, wody, powietrza, ognia) i masy przyrostowej. Te pierwsze są niezmienne, ta druga ulega nieustannej modyfikacji w wyniku procesów metabolicznych. Dla potwierdzenia swojej teorii Metody przytaczał wiele ,argumentów” empirycznych. Wskazał m.in. na sposób gojenia się ran. Jeżeli goi się ona bez śladu, to znaczy, że uszkodzeniu uległy tylko części przyrostowe, jeżeli natomiast powstanie blizna - to znaczy, że uszkodzone zostały elementy konstytutywne. Innym przykładem są włosy i paznokcie, które odrastają, ponieważ są ciałem przyrostowym; natomiast amputowana kończyna nie regeneruje się, ponieważ stanowi część konstytutywną ${ }^{29}$.

27 Pytanie to jest aktualne do dziś. Współczesna teologia unika jednoznacznej odpowiedzi, czego wyrazem jest dokument Międzynarodowej Komisji Teologicznej o aktualnych problemach eschatologicznych (1979). Znajduje się w nim ogólnikowe stwierdzenie, że do tożsamości ciała nie jest konieczna ta sama materia. W kontekście kultu relikwii podkreślono jednak, że zmartwychwstania nie da się wyjaśnić niezależnie od ciała ziemskiego, por. Enchiridion Vaticanum, t. 13, Bologna 1995, 283 (n. 473).

${ }^{28}$ Methodius, De resurrectione, ed. G.N. Bonwetsch, GCS 27, Leipzig 1917, 219-424.

${ }^{29}$ Por. tamże II 13, 5-6. 
Swoją teorię Metody zastosował również do wyjaśnienia rodzajów krwi, dzieląc ją na konstytutywną i przyrostową (humoralną). W jego opinii, stosowana przez starożytnych lekarzy praktyka upuszczania krwi, polegała właśnie na eliminowaniu nadmiaru krwi humoralnej. W takim kontekście pojawia się zagadnienie menstruacji. Występuje ona u kobiet $\mathrm{z}$ powodu zbyt małego wysiłku fizycznego. Mężczyźni bowiem, którzy dużo ciężej pracują, przekształcają nadmiar krwi w pot ${ }^{30}$. Takie rozumienie menstruacji i jej przyczyn Metody zaczerpnął najprawdopodobniej od Arystotelesa, który starał się wyjaśnić ten fenomen za pomocą teorii ciepła.

Metody uważał (choć skąpe opisy, a właściwie wtrącenia przy omawianiu innych kwestii zmuszają do powściagliwej oceny jego poglądów na ten temat), że to, co współczesna medycyna nazywa ,żeńską komórką płciową”, jest rodzajem krwi. Wskazywał na powtarzający się cykl jej gromadzenia się i utraty, uzależniając od jej ilości żeńską płodność. Sugerował, że okresy płodne pojawiają się wtedy, kiedy przyrośnie odpowiednia porcja krwi humoralnej. Kobieta staje się wtedy silniejsza, a zmiany w jej organizmie są rozpoznawalne nawet $\mathrm{w}$ wyglądzie zewnętrznym. Jeżeli $\mathrm{w}$ tym czasie dochodzi do stosunku z mężczyzna, wtedy zazwyczaj następuje poczęcie dziecka, gdyż żeński organizm jest nastawiony na przyjmowanie i gromadzenie wszystkich substancji, a nie na wydalanie ich nadmiaru $w$ procesie miesięcznego oczyszczenia ${ }^{31}$.

b) Prokreacja i godność poczętego dziecka. Zagadnienie poczęcia człowieka zostało podjęte przez Metodego, paradoksalnie, w dziele Symposium. Pierwsza mówczyni, Marcella, przedstawiając etapy doskonalenia się ludzkości w dziedzinie seksualności i relacji męsko-żeńskich - od związków rodzinnych i klanowych, poprzez poligamię i monogamię, aż po dziewictwo przyniesione przez Chrystusa - zasugerowała powołanie wszystkich chrześcijan do życia tym najwyższym ideałem. Przemawiająca po niej Teofila podjęła wyraźną polemikę z poglądami poprzedniczki. Jej wystapienie to zdecydowana obrona instytucji małżeństwa i aktualnego sposobu ludzkiej prokreacji, uznanego przez nią za odwieczne Boże postanowienie. Jej przemowa to w dużej mierze alegoryczna interpretacja Rdz 2, 21-24, to jest snu Adama i stworzenia kobiety. Warto dodać, że Teofila została przez swoje słuchaczki nagrodzona długą i radosną owacją, co nie zdarzyło się nawet w przypadku zwyciężczyni agonu, Tekli32

Treść egzegezy Teofili, bardziej teologiczna niż fizjologiczna, jest niezwykle oryginalna:

„Otóż początkiem aktu powstania człowieka jest rzucenie nasienia w matczyną glebę po to, żeby kość z kości i ciało z ciała, ogarnięte tajemniczą mocą

${ }^{30}$ Por. tamże II 13, 2-3.

${ }^{31}$ Por. tamże II 20, 5. Pogłębione ujęcie tego zagadnienia w myśli patrystycznej, zob. P. Laurence, La faiblesse féminine chez les Pères de l'Eglise, w: Les Perès de l'Eglise face à la science médicale de leur temps. Actes du troisième colloque d'études patristiques (Paris, 9-11 septembre 2004), éd. V. Boudon-Millot - B. Pouderon, Théologie historique 117, Paris 2005, 351-377.

${ }^{32}$ Por. Methodius, Symposium VIII. 
przez samego Stworzyciela, spowodowały narodziny nowego człowieka. I trzeba uznać, że w ten sposób spełnia się powiedzenie: «Oto dopiero jest kość z kości moich i ciało z ciała mojego» ( $\mathrm{Rdz} 2,23)$.

Prawdopodobnie bowiem takim właśnie znakiem była senna ekstaza zesłana na pierwszego człowieka, która symbolizowała oczarowanie mężczyzny miłością: spragniony płodzenia dzieci ulega oszołomieniu, owładnięty popędem seksualnym i rozkoszami, które mu się we śnie ukazały, aby znowu oderwana cząstka jego kości i ciała ukształtowała się, jak powiedziałam, w innego człowieka. Albowiem, jak nas pouczają ludzie wtajemniczeni w sprawy małżeńskie, na skutek zakłócenia harmonii cielesnej przez seksualne podniety ciała, podobna do szpiku, bardzo płodna cząsteczka krwi, która jest jakby płynną kością, zebrana ze wszystkich członków, spieniona i gęsta spływa przez narządy płciowe na żywą glebę kobiety.

$Z$ tego też względu słusznie powiedziano, że mężczyzna «opuści ojca i matkę» (Rdz 2, 24), nie pamiętając o niczym, gdy spleciony z kobietą w miłosnych uściskach ulega rozrodczej namiętności i pozwala boskiemu Stworzycielowi wyjąć sobie żebro, aby z syna stał się z kolei ojcem. Jeśli więc jeszcze w naszych czasach Bóg stwarza człowieka, to czyż nie jest zuchwalstwem odczuwanie wstrętu do prokreacji, skoro nawet Wszechmogący nie wstydzi się przykładać do niej swoich nieskazitelnych rąk?"33.

Ogólny kontekst wypowiedzi Teofili jest wyraźnie antyenkratyczny. Stanowi też bezpośrednia, choć subtelną, polemikę z tymi poglądami ascetycznymi (reprezentowanymi w Symposium przez Marcellę), które z dziewiczego stylu życia Chrystusa chciały uczynić normę generalną, obejmującą wszystkich Jego wyznawców.

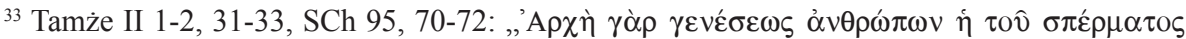

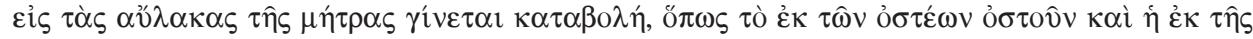

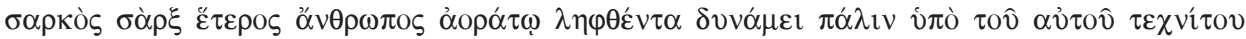

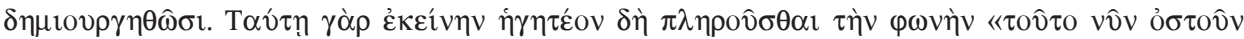

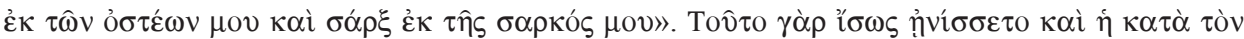

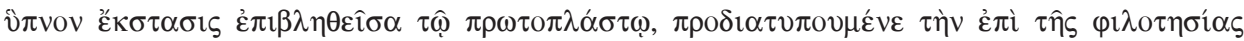

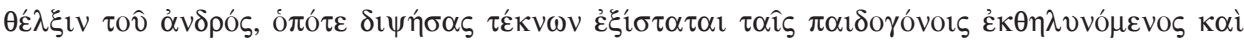



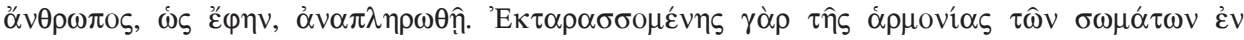

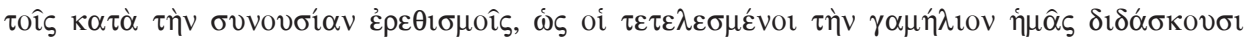

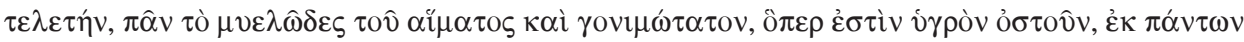

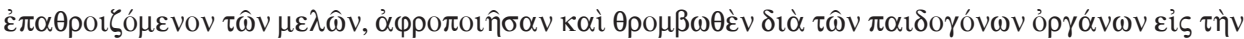

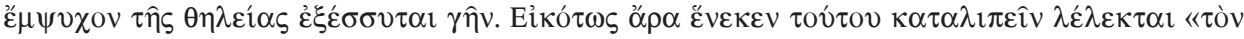

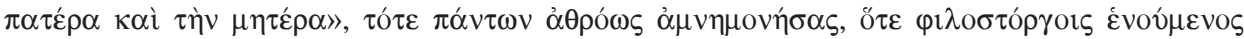
$\tau \hat{~}$

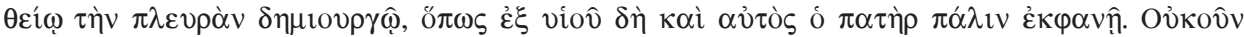

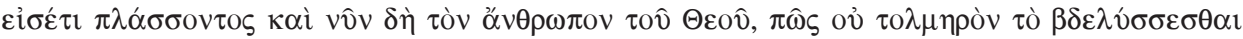

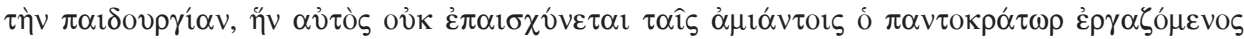

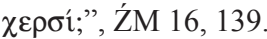


Poszczególne elementy passusu Rdz 2, 21-24 zostały zinterpretowane przez Teofilę jako prefiguracje dynamiki aktu seksualnego, podczas którego męskie nasienie (symbolizowane przez żebro Adama) daje początek nowemu człowiekowi. Wyjątkowość tej interpretacji polega na tym, że punktem odniesienia dla ujętej w niej typologii jest rzeczywistość fizjologiczna ${ }^{34}$. Metody poświęcił dużo uwagi wyjaśnieniu natury i pochodzenia spermy. Odchodząc od stanowiska Arystotelesa, połączył trzy znane w starożytności koncepcje (mielogenetyczną, pangenetyczną i hemogenetyczną) w synkretyczną całość, bardziej spójną z teorią czterech elementów wchodzących w skład organizmu, a jednocześnie wykazująca zbieżność z wersetem $\mathrm{Rdz} 2$ 2, 23: „Oto dopiero jest kość z kości moich i ciało z ciała mojego" "35. Terminologia dotycząca żeńskiej anatomii jest natomiast dosyć uboga. Metody mówił o drogach rodnych

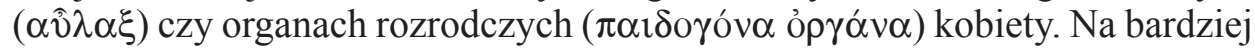
precyzyjne oznaczenie łona (macicy) używał technicznego terminu $\mu \eta \dot{\tau} \tau \rho \alpha$ lub

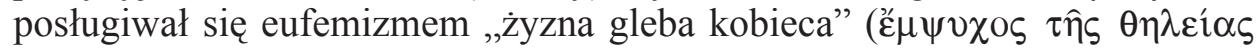
$\gamma \widehat{\eta})$. W Symposium III 8 termin $\mu \eta \dot{\tau} \rho \alpha$ występuje w znaczeniu przenośnym na oznaczenie łona Kościoła, w którym rodzą się nowi wierni.


gą tradycję egzegetyczną. Przykładowo, Filon z Aleksandrii ( $\dagger$ ok. 40 po Chr.) upatrywał w nim symbol wzniesienia się ponad zmysłowość w celu doświadczenia rzeczywistości duchowych (rozumnych). „Żebro” natomiast interpretował we właściwej mu optyce alegorezy spirytualizującej, jako symbol mocy ${ }^{36}$.

Metody z pewnością znał tego rodzaju egzegezę Rdz 2, 21-24. W sposób wyraźny i zdecydowany przeciwstawiał się teoriom mówiącym o jakichś „duchowych kościach"37 Adama i Ewy. Stwierdzał stanowczo, że człowiek, będący ,jednością duszy i ciała połączonych w jednej formie piękna"38, został od początku stworzony na obraz i podobieństwo Boże. W Symposium II, wydobywając $\mathrm{z}$ tekstu protologicznego, i to w pierwszej kolejności, treść dotyczącą ciała i fizjologii wyrażał nie tylko swoje najgłębsze przekonanie o jednorazowości aktu stworzenia człowieka jako bytu cielesno-duchowego ${ }^{39}$,

${ }^{34}$ Trzecia mówczyni, Talia (tamże III) zaprezentowała inną, choć komplementarną w stosunku do poprzedniej, alegorezę Rdz 2, 21-24. Odczytując ten passus w świetle Ef 5, 28-32, odniosła go do związku Chrystusa i Kościoła.

${ }^{35}$ Werset Rdz 2, 23, przywołał wcześniej Klemens Aleksandryjski (Paedagogus II 10, 94, 4) podczas wyjaśniania fenomenu osłabienia mężczyzny po odbyciu stosunku seksualnego.

${ }^{36}$ Por. Philo Alexandrinus, Legum allegoriae II 19; II 26; II 29.

${ }^{37}$ Por. Methodius, De resurrectione I 39, 2.

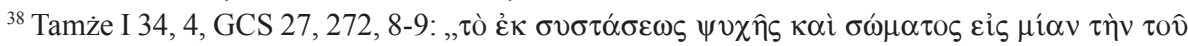

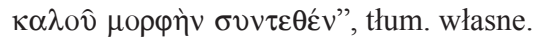

${ }^{39} \mathrm{~W}$ tzw. tradycji azjatyckiej (Tertulian, Ireneusz i inni) dwa opisy stworzenia człowieka z Księgi Rodzaju uznawano jako komplementarne i wyjaśniające w różny sposób ten sam jedyny i jednorazowy akt; w tradycji aleksandryjskiej, natomiast, rozpowszechniona była teoria o dwu-, a nawet trzyetapowym procesie stworzenia człowieka, tj. poszczególnych komponentów jego natury: duszy (Rdz 1, 26-27), ciała eterycznego (Rdz 2, 7), ciała zmysłowego (Rdz 3, 21). 
ale także podkreślał pozytywny charakter aktu małżeńskiego, którego forma została ustanowiona przez Boga Stworzyciela.

Jest niezwykle wymowne, że w całym Symposium Metody nie przywołał tych wersetów biblijnych, które były wykorzystywane przez enkratytów dla potwierdzenia ich opinii o grzeszności ludzkiej prokreacji jak np. Ps 51, 7: „Oto zrodzony jestem w przewinieniu i w grzechu poczęła mnie matka”; Hi 14, 4-5: „Któż czystym uczyni skalane? Nikt zgoła”. To opuszczenie nie jest jedynie przypadkiem, ale rzeczywistym argumentem ex silentio. Biskup Olimpu bowiem doskonale znał Księgę Hioba, do której napisał specjalny komentarz, a w tekst Symposium II wplótł z niej pewne cytaty. Wspomniane wyżej wersety biblijne przywołał natomiast w De resurrectione, wkładając je w usta heterodoksów, których opinie poddał bezwzględnej krytyce. W całym rozumowaniu Metodego i we wszystkich jego dziełach widać ogromną troskę o to, by nie łączyć seksualności jako takiej z grzechem. Nie ma w jego pismach sugestii (co miało miejsce np. u Klemensa Aleksandryjskiego ${ }^{40}$ ) jakoby grzech pierwszych rodziców polegał na przekroczeniu przykazania Bożego w tej właśnie sferze życia ${ }^{41}$.

Kolejnym celem rozważań Metodego było uzasadnienie ludzkiej godności i fundamentalnej wartości każdego poczętego dziecka. Teofila, w polemice z Marcellą, stara się dowieść, że Bóg uczestniczy w akcie prokreacji nawet wtedy, gdy następuje ona w wyniku cudzołóstwa. Winny jest bowiem ten, kto rzuca nasienie na cudzą glebę, a nie samo ziarno. Jest to jeden z najbardziej odważnych tekstów patrystycznych ukazujących, że Bóg nawet ze zła potrafi wyprowadzić dobro, i że grzech człowieka nie jest przeszkodą dla Jego stwórczego i zbawczego działania.

Dla potwierdzenia swojej opinii, a jednocześnie zilustrowania procesu powstawania człowieka, Teofila kreśli sugestywny obraz manufaktury (będącej symbolem łona kobiecego), we wnętrzu której ukryty artysta wytwarza piękne rzeźby z gliny, którą ludzie dostarczają z zewnątrz przez odpowiednie otwory. Każdemu dostawcy materiału przydzielony jest tylko jeden otwór. Za nieuczciwe podrzucenie gliny w innym miejscu grozi surowa kara. Zasadniczym celem tej rozbudowanej przez Teofilę metafory potępiającej cudzołóstwo było stwierdzenie, że „wewnętrzny artysta” z jednakowym kunsztem obrabia każdy materiał, niezależnie przez kogo i w jaki sposób został dostarczony ${ }^{42}$.

Co na podstawie tych metafor można powiedzieć o rozumieniu przez Metodego przebiegu i natury poczęcia? Wydaje się, że przypisywał on kobiecie

${ }^{40}$ Klemens Aleksandryjski (Stromata III 14, 94, 3) twierdził, że grzech pierwszych rodziców polegał na przedwczesnym skosztowaniu czaru małżeństwa.

${ }^{41}$ Por. E. Prinzivalli, Desiderio di generazione e generazione del desiderio. Metodio di Olimpo e le polemiche sull'eros fra III e IV secolo, w: L'eros difficile, s. 55.

${ }^{42}$ Por. Methodius, Symposium II 4, 38-40. Jednoznaczne aksjologiczne rozróżnienie pomiędzy metodą a owocem zapłodnienia może stanowić pomocny argument historyczny w aktualnych dyskusjach wokół etycznych aspektów procedury zapłodnienia pozaustrojowego, tzw. in vitro. 
jedynie bierną rolę w procesie prokreacji. Jej łono porównywał do ,żyznej gleby”, która przyjmuje nasienie albo do „pieca” (dziś powiedzielibyśmy: do ,inkubatora”), w którym rozwija się zarodek uformowany przez męską siłę rozrodczą ${ }^{43}$.

Chociaż w dziełach Metodego nie znajdujemy drobiazgowych rozważań o pochodzeniu i naturze spermy i krwi menstruacyjnej, to jednak z pewnością interesowała go ludzka fizjologia. Pomimo oczywistej zależności od starożytnych autorów pogańskich, warto zwrócić uwagę na kilka szczegółów, które znamionują pewien dystans Metodego wobec teorii Arystotelesa i ich twórczą modyfikację, głównie z racji teologicznych. Widać ją np. w koncepcji pochodzenia spermy, o czym była już wyżej mowa. Najbardziej znaczące są jednak różnice filozoficzno-teologiczne. O ile Arystoteles uznawał spermę mężczyzny za jedyny czynnik aktywny i formalny w tworzeniu płodu, o tyle Metody przypisał większość tych funkcji samemu Bogu. Biskup Olimpu nie tylko odrzucił pogląd, że dusza ludzka jest przenoszona przez nasienie, ale wyrażał wattpliwość czy jest ono samo z siebie zdolne do przekształcania się w człowieka:

„Może w tym miejscu skorzysta ktoś z okazji i użyje wobec ludzi niewykształconych i prostych takiego oto argumentu: «Owo cielesne odzienie duszy zasiane przez ludzi kształtuje się samo, niezależnie od wyroku Boga». Nie zasłuży on jednak na uwagę, ucząc, że substancja duszy jest zasiewana razem ze śmiertelnym ciałem. Temu bowiem, co nieśmiertelne i co się nie starzeje, jedynie Wszechmogący udziela tchnienia i dlatego jest On również jedynym Twórcą rzeczy niewidzialnych i niezniszczalnych"44.

Metody, uznawszy Boga za realny i aktywny podmiot kształtujący każde dziecko w łonie matki, zredukował rolę przypisywaną przez Arystotelesa męskiemu nasieniu. Sprowadził je do roli materiału, który po połączeniu z żeńską krwią rozrodczą, Bóg formuje i ożywia przez połączenie ze stworzoną bezpośrednio przez siebie duszą. Po przywołaniu kilku cytatów biblijnych, mówiących o kształtowaniu człowieka w łonie matki (Jr 1, 5; Hi 38, 14; Hi 10, 8) Teofila expressis verbis uznała sprawcze działanie Stwórcy:

„Bez Bożego współdziałania natura nie dokonałaby tak wielkiego dzieła. Któż bowiem utwardził miękką substancję kości? Kto spoił giętkie członki tak, żeby za pomocą mięśni zginały się i prostowały w stawach? Jaki Bóg

${ }^{43}$ Por. tamże II 4; II 6.

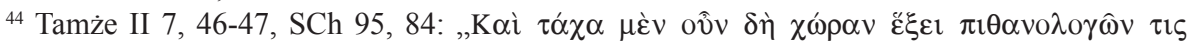

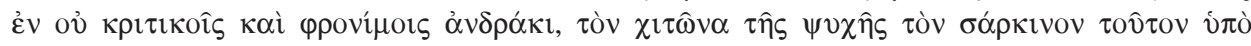

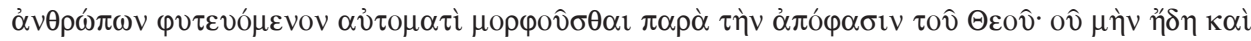

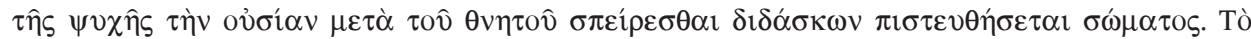

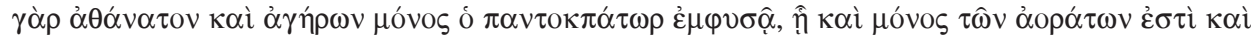


1, GCS 27, 372: „Nie uważamy, że wzrost zależy od siły nasienia, ale od mocy Boga”, tłum. własne.

${ }^{45}$ Por. Methodius, Symposium II 2, 33. 
doprowadził do fermentacji organiczny sok przez zwilżenie go krwią i utworzył z prochu delikatne ciało, jeśli nie jedyny i najlepszy Stwórca, który modelując jak wosk wilgotne i maleńkie nasionka w kobiecym łonie wytworzył nas jako swój najrozumniejszy obraz i uczynił z nas obdarzonych duszą ludzi?"”6

$\mathrm{Na}$ tle starożytnych poglądów, przypisujących kobiecie jedynie pasywną rolę $\mathrm{w}$ procesie prokreacji, fundamentalnie teologiczna wizja rozrodczości, wysunięta przez Metodego, uwydatnia i dowartościowuje, także w przestrzeni fizjologicznej, funkcję matki. Znaczenie żeńskiej krwi rozrodczej jest prawie równie ważne jak materiału dostarczanego przez mężczyznę. Żadne z nich nie jest „twórcą” nowego życia, lecz współuczestniczy - we właściwy każdej płci sposób - w stwórczym dziele, które Bóg nieustannie kontynuuje. Co więcej, Metody przeniósł niejako punkt ciężkości prokreacji z męskiego nasienia na łono matczyne, w którym Bóg nie tylko kształtuje ludzkie ciało, ale gdzie dokonuje także jego połączenia $\mathrm{z}$ duszą ${ }^{47}$.

Pozytywnej, a wręcz aktywnej roli kobiety w prokreacji, można się dopatrzeć w przemówieniu Tekli ${ }^{48}$. Zwyciężczyni oratorskiego konkursu uznaje rozrodczość kobiety za figurę płodności Kościoła, który we chrzcie rodzi swoje dzieci do życia:

„Albowiem jak kobieta przyjąwszy nieuformowane nasienie mężczyzny po upływie określonego czasu rodzi pełnego człowieka, tak też można powiedzieć, iż Kościół wciąż poczyna w sobie tych, którzy uciekają się do Słowa, a kształtując i modelując ich na obraz i podobieństwo Chrystusa, po upływie określonego czasu tworzy z nich obywateli owych szczęśliwych wieków"49.

Zarówno w wystapieniu Tekli, jak i we wzmiankowanej wcześniej mowie Talii, Metody nie zawahał się uznać ludzkiej seksualności i prokreacji za typologię rzeczywistości kościelnych i Bożych. Talia, potwierdzając słuszność rozważań Teofili, starała się na podstawie Ef 5, 28-32 wskazać duchowy sens opisu stworzenia kobiety. Podstawa jej rozumowania pozostała jednak typologia fizjologiczna, którą odniosła do rzeczywistości nowotestamentalnych. Śpiący Adam symbolizuje Chrystusa umierającego na krzyżu po to, by zrodziła się

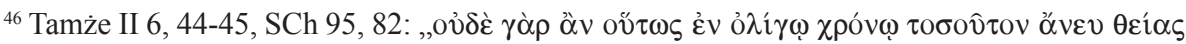

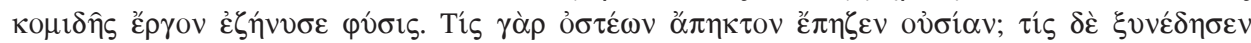

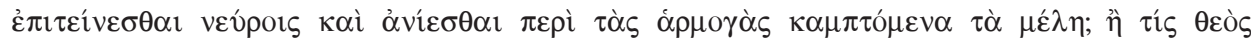



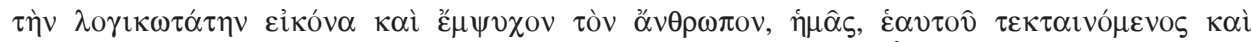

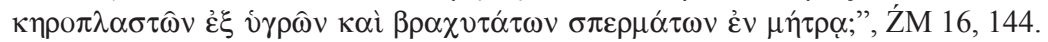

${ }^{47}$ Por. Prinzivalli, Donna e generazione nei Padri della Chiesa, s. 88-89.

${ }^{48}$ Por. Methodius, Symposium VIII.

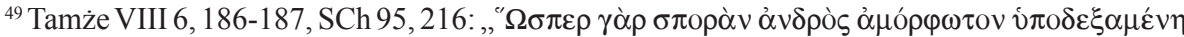

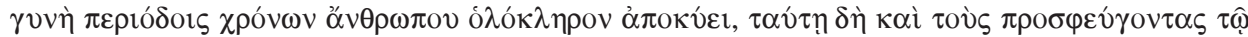

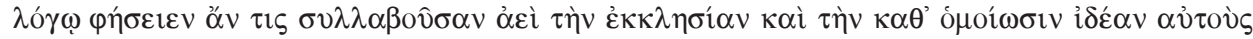

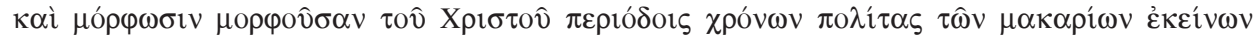

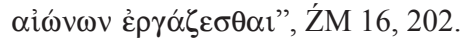


Jego żona (czyli Kościół), a Jego żebro to duchowe i błogosławione nasienie, czyli Duch Prawdy, Pocieszyciel ${ }^{50}$.

Zjednoczenie cielesne mężczyzny i kobiety nie było więc dla Metodego jakimś dalekim i wykrzywionym obrazem jedności i płodności duchowej, jak to interpretowano w środowiskach platonizujących chrześcijan, ale było rozumiane jako ustanowiona przez samego Stwórcę figura komunii Chrystusa i Kościoła.

c) Warunki życia prenatalnego. Teologiczna wizja formowania się istoty ludzkiej wpłynęła także na postrzeganie przez Metodego okresu brzemienności. W celu podkreślenia mocy Boga i Jego cudownej troski o dziecko przeciwstawił je ,trudnym warunkom bytowym” okresu płodowego:

„Kim jest Ten, który się troszczy, żeby zarodek umieszczony wewnątrz ciała matki nie udusił się w wilgoci i ciasnocie?"’1

Podobne rozumowanie Metody przeprowadził w De resurrectione, podkreślając troskę Boga o rozwój płodu ludzkiego. Stwierdził, że bez szczególnej asystencji Stwórcy płód zadusiłby się lub ugotował z powodu wysokiej temperatury krwi w łonie matki lub mógłby być zniszczony w okresie cyklu menstruacyjnego ${ }^{52}$.

Odwołanie do rzeczywistości prokreacyjnej i prenatalnej w dziele mającym na celu uzasadnienie zmartwychwstania ciała należało w początkach IV w. do podstawowego arsenału chrześcijańskiej argumentacji rezurekcyjnej. Wyrażano w ten sposób przekonanie, że dużo łatwiej jest „zrekonstruować” ciało, które się rozpadło, niż stworzyć je z niczego (ewentualnie uformować z maleńkiego ludzkiego nasienia) ${ }^{53}$. Nie chodziło tu o deprecjonowanie czy pogardę matczynego łona, ale o podkreślenie roli Boga. Tak, jak mocen jest On powołać człowieka do życia i pozwolić mu przyjść na świat, pomimo trudności okresu prenatalnego, podobnie jest zdolny uformować z powrotem ludzkie ciało, które śmierć zamieniła w proch ziemi, i wprowadzić je do pełni życia w zmartwychwstaniu. Choć rozum ludzki nie jest w stanie tego precyzyjnie wyjaśnić, potrafi przynajmniej wykazać racjonalność rezurekcyjnej nadziei i rozpoznać znaki jej obecności w aktualnym świecie.

2. Ambroży z Mediolanu. Kolejnym autorem, który w swoich pismach dosyć często odwoływał się do różnorodnych zagadnień fizjologicznych i medycznych, w tym do rozrodczości, był Ambroży, biskup Mediolanu ${ }^{54}$. Wydaje

${ }^{50}$ Por. tamże III 8, 70-74.

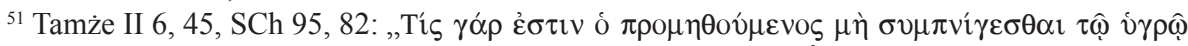

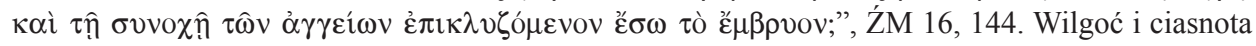
łona kobiecego są przywołane też w De resurrectione II 20, 7.

${ }^{52}$ Por. tenże, Symposium II 20, 4. 6.

${ }^{53}$ Ten rodzaj argumentacji rezurekcyjnej wysunęli przed Metodym: Justinus, Apologia I 19, 1-5; Ps.-Justinus, De resurrectione V 5; Teophilus, Ad Autolicum I 8.

${ }^{54}$ Por. R. Passarella, Conoscenze mediche ambrosiane, ovvero la medicina nei Padri della Chiesa: questioni di metodo, „Acme” 57 (2004) fasc. 2, 69-91. 
się, że jego zainteresowanie fizjologią kobiety oraz etiologią i dynamiką płodności było w dużej mierze pochodną przesłanek teologicznych, a szczególnie wyjątkowej roli Maryi w historii zbawienia. Podejmując tematy mariologiczne, Ambroży próbował zmierzyć się z takimi zagadnieniami fizjologicznymi, jak: poczęcie, rozwój prenatalny, narodziny, dziewictwo itp. Rozważania teologiczne stanowiły z kolei wymarzoną okazję do wyrażenia pouczeń moralnych i duszpasterskich oraz udzielenia bardzo praktycznych wskazówek.

a) Anatomiczny i fizjologiczny wymiar kobiecej płodności. Ambroży, podejmując tematykę rozrodczości, nie opisywał w sposób szczegółowy anatomii kobiecej. Używana przez niego terminologia, zbieżna $\mathrm{z}$ tą medyczną jego czasów ${ }^{55}$, odnosiła się do narządów rodnych jako jednej całości i zazwyczaj w sposób ogólny. Najczęstsze pojęcia to: genitalia ${ }^{56}$, przymiotnik genitalis złączony z terminem claustra ${ }^{57}$ lub secretum ${ }^{58}$, oraz ogólne słowo: natura ${ }^{59}$. Ambrozjańskim neologizmem jest natomiast pojęcie generatorium, używane w znaczeniu tak dosłownym ${ }^{60}$, jak i przenośnym ${ }^{61}$. Mówiąc $w$ sposób bardziej precyzyjny o łonie kobiecym (macicy), biskup Mediolanu używał pojęć takich, jak: venter, uterus, alvus, vulva, matrix ${ }^{62}$. Duszpasterski charakter jego tekstów każe przypuszczać, że wnikliwe pouczenia medyczne nie stanowiły jedynie przykładów pomocnych egzegezie, ale służyły także wychowaniu i przekazaniu kobietom wiedzy ginekologicznej.

W kilku tekstach Ambrożego pojawia się np. temat kobiecej płodności, uznanej za wyraz Bożego błogosławieństwa ${ }^{63}$. Jako jej początek, zgodnie $z$ ówczesnymi teoriami medycznymi ${ }^{64}$, wskazuje on wiek czternastu lat, kiedy to powinien rozpocząć się cykl menstruacyjny ${ }^{65}$. Podkreśla, że okres płodności, w którym organizm kobiety ulega głębokim przemianom (np. wzrostem

${ }_{55}^{55}$ Por. J. André, Le vocabulaire latin de l'anatomie, Paris 1991.

${ }^{56}$ Por. Ambrosius, De Abraham I 8, 66; tenże, Exameron VI 9, 9, 73; tenże, Explanatio super Ps. 61, 32; Epistula VI 27, 10. Oprócz pierwszego passusu, w którym jest mowa o organach rodnych Sary (Sarrae genitalia), pozostałe odnoszą się w sposób ogólny do obydwu płci.

${ }^{57}$ Por. tenże, De institutione virginis VIII 52 i 55.

${ }^{58}$ Por. tenże, Epistula VIII 56, 5; tenże, Expositio Evangelii secundum Lucam II 57.

${ }^{59}$ Por. tenże, De apologiae prophetae David XI 56.

${ }^{60}$ Por. tenże, De Noe XII 40.

${ }^{61}$ Por. tenże, Expositio de Psalmo CXVIII 18, 11.

${ }^{62}$ Por. R. Passarella, Aspetti di medicina ginecologica e pediatrica nell'opera di Ambrogio, SEA 101, Roma 2007, 580-581.

${ }^{63}$ Por. Ambrosius, Expositio Evangelii secundum Lucam I 30.

${ }^{64}$ Por. D. Gourevitch, Le mal d'être femme. La femme et la médecine dans la Rome antique, Paris 1984, 84-85. Fakt fizjologicznego początku płodności stanowił podstawę obyczajowych i prawnych określeń dotyczących możliwości i czasu zawierania małżeństwa, zob. H. King, Hippocrates ' Woman. Reading the female body in Ancient Greece, London - New York 1998, 23.

${ }^{65}$ Por. Ambrosius, De Abraham II 11, 78. Informacja o menstruacji pojawia się w kontekście wzmianki o staroegipskiej praktyce obrzezania chłopców w wieku czternastu lat, kiedy to budzi się u nich pragnienie seksualne. 
piersi $\left.{ }^{66}\right)$, jest czasem szczególnym, który należy dobrze wykorzystać. W kontekście rozważań nad duszą, której właściwości nie zależą od płci osoby, Ambroży wzmiankuje o ograniczonym okresie biologicznej płodności kobiety.

„Jak kobietom natura dała macicę, w której, w okresie trwania cyklów menstrualnych, poczyna się i formuje każdy żywy organizm, tak też jest pewna sprawność duszy, która jakby w głębi kobiecego łona przyjmuje nasienie naszych myśli, odżywia to, co zostało poczęte, wydaje na świat owoce"67.

Ambroży nie wskazał w sposób precyzyjny momentu kobiecej menopauzy. Komentując jednak passus Rdz 17, 16-17 (obietnica legalnego potomstwa złożona Abrahamowi) stwierdził, że w wieku 90. lat narządy rodne Sary musiały być już obumarłe ${ }^{68}$. W takich okolicznościach jeszcze pełniej mogła się wyrazić siła wiary Patriarchy, którą nie zachwiały ani starość, ani niepłodność żony ${ }^{69}$.

Ambroży zdawał sobie sprawę jak wielkim dramatem jest niepłodność, której skutki obciążały dotknięte nią kobiety nie tylko w wymiarze osobistym (fizycznym i psychicznym), ale także rodzinnym, społecznym i religijnym ${ }^{70}$. Zgodnie z wyobrażeniami medycznymi za jej główną przyczynę uznawał niewłaściwe ułożenie lub przesunięcie się macicy. Użyty przez niego termin peridrome $^{71}$ na oznaczenie tej patologii jest jedynym znanym w literaturze łacińskiej świadectwem tej nazwy ${ }^{72}$. Biblijne przykłady (Sara, Elżbieta) tego schorzenia były dla niego punktem wyjścia i kluczową wskazówką odnośnie sposobu traktowania tego problemu. Ambroży wskazywał, że ciężar niepłodności fizycznej może być przezwyciężony przez płodność duchową polegającą na wydawaniu owoców cnót ${ }^{73}$. Nade wszystko podkreślał, że także w tym szczególnym dramacie kobiety (i jej męża) Bóg może objawić swoją potęge i cudowne działanie:

„Istotnie, jego [Abimeleka] żona i niewolnica urodziły, po tym, jak Pan zamknął [ich łona] z powodu Sary, żony Abrahama (por. Rdz 20, 17-18). Było to częścią [Bożego] planu, aby narodziny dziecka Sary, obiecane przez Boga, były w ten sposób godnym świadectwem i przestrogą przed obrażaniem Boga, który kobiety zdrowe czyni niepłodnymi i przeciwnie, kobiety niepłodne,

\footnotetext{
${ }^{66}$ Por. tenże, Expositio de Psalmo CXVIII 22, 35.

${ }^{67}$ Tenże, De Cain et Abel I 10, 47, ed. P. Siniscalco, SAEMO 2/I, Milano - Roma 1984, 244: „sicut feminis dedit vulvam natura, in qua uniuscuiusque animantis generatio per menstruas formatur aetates, ita est quaedam virtus animae, quae velut quodam vulvae genitalis secreto cogitationum nostrarum suscipere semina, conceptus fovere partusque solet edere", thum. własne.

${ }^{68}$ Por. tenże, De Abraham I 5, 42.

${ }^{69}$ Por. tamże I 8, 66.

${ }^{70} \mathrm{~W}$ starożytności niepłodność przypisywano zazwyczaj kobiecie.

${ }^{71}$ Por. tenże, Expositio de Psalmo CXVIII 19, 1.

${ }^{72}$ Por. Passarella, Aspetti di medicina, s. 595.

${ }^{73}$ Por. Ambrosius, Epistula IX 62, 11.
} 
z woli Pana, stają się zdolne do rodzenia, jak to zostało napisane: «czy to nie Ja czynię kobietę niepłodną lub zdolną do rodzenia - mówi Pan»"74.

W kontekście rozważań o zwiastowaniu Maryi, Ambroży w bardzo odważnych słowach podkreślał odmienność sposobu poczęcia Jezusa w stosunku do innych ludzi:

„albowiem nie współżycie z mężczyzną otworzyło tajnię dziewiczego łona, lecz nieskalane nasienie Duch Święty wlał w nienaruszone łono"75.

Poetycki termin reserare był często używany w elogiach miłosnych obrazując czynność otwierania zamkniętych drzwi, które normalnie pozostawały zamknięte. U Ambrożego współgra on z takimi pojęciami, jak: porta czy claustrum, używanymi dla metaforycznego określenia żeńskich narządów płciowych. W kilku jego tekstach pojawia się ponadto czasownik deflorare (dosłownie: „zerwać kwiat”) i rzeczownik defloratio, terminy, które w początkach V w. nie posiadały jeszcze znaczenia technicznego ${ }^{76}$. Być może to właśnie Ambroży, łącząc je z takimi pojęciami, jak: pudor, virginitas, usus coniugii, iuventus etc., przyczynił się do ich semantycznej ewolucji. W ten sposób zawierający nutę delikatności czasownik deflorare przyjął z czasem znaczenie pojęcia devirginare ${ }^{77}$.

b) Stan błogosławiony i macierzyństwo. Szczególnym zainteresowaniem Ambrożego cieszył się stan błogosławiony i jego wielorakie aspekty. Kiedy zwracał uwagę na trudy brzemienności, używał czasownika gravare czy przymiotnika gravis, natomiast sam moment biologicznego poczęcia opisywał takimi terminami, jak: accipere, concepire, suscipere, połączonymi często $\mathrm{z}$ precyzyjnym wskazaniem miejsca, tj. łona - (in) utero ${ }^{78}$. Kolejny wyraźnie wyróżniony aspekt to rozwój poczętego dziecka, wyrażany takimi czasownikami, jak: formare, adolescere, coalescere, fovere. Interesującym terminem na oznaczenie embrionu we wczesnej fazie rozwoju jest rzeczownik concretio.

${ }^{74}$ Tenże, De Abraham I 7, 61, ed. F. Gori, SAEMO 2/II, Milano - Roma 1984, 98: „Peperit enim uxor eius et ancilla illius, quas ante concluserat dominus propter Sarram uxorem Abrahae. Quod aeque ad oeconomiam pertinet, ut Sarrae partus dei donatus promissione etiam hoc fulciretur testimonio, cum advertas dei offensione et fecundas steriliscere et rursus domini voluntate steriles fecundari iuxta quod scriptum est: «nonne sterilem et parientem ego feci? - dicit dominus» (por. Iz 66, 9)", thum. własne.

75 Tenże, Expositio Evangelii secundum Lucam II 56, ed. G. Coppa, SAEMO 11, Milano Roma 1978, 196: „Non enim virilis coitus vulvae virginalis secreta reseravit, sed inmaculatum semen inviolabili utero spiritus sanctus infudit”, thum. W. Szołdrski: Św. Ambroży, Wykład Ewangelii wedtug św. Łukasza, PSP 16, Warszawa 1977, 74.

${ }^{76}$ Por. tenże, De Cain et Abel I 10, 46; tenże, De Iacob et vita beata II 7, 32; tenże, De viduis 88; tenże, Epistula VI 56, 11; tenże, De institutione virginis VI 41; tenże, Exhortatio virginitatis VI 35; tenże, Expositio Evangelii secundum Lucam VIII 4.

${ }^{77}$ Por. Petronius Arbiter, Satyricon 25, 2; Hieronymus, In Hiezechielem VII 23, 3, ed. F. Glorie, CCL 75, Turnhout 1964, 303, 771; 304, 786.

${ }^{78}$ Por. Passarella, Aspetti di medicina, s. 585. 
Używany początkowo dla opisania efektu fermentacji mleka, czyli jego ścinania się ${ }^{79}$, stał się z czasem technicznym terminem starożytnej „embriologii”.

Wiedza biologiczno-medyczna i wszystkie pojęcia służyły mu bardzo często do wyjaśnienia pewnych prawd teologicznych. Jedną z najważniejszych było wcielenie. Biskup Mediolanu z dużą precyzją i wnikliwością wykazywał, że poczęcie Jezusa - także na poziomie biologicznym - dokonało się w inny sposób, niż u wszystkich ludzi.

„«Ty mnie począłeś przez wzgląd na mą prawość». Co zatem oznacza takie poczęcie? Także gdzie indziej możemy przeczytać: «Począłeś mnie w łonie mej matki». Tak więc nieskażony przez żadne współżycie właściwe rodzajowi ludzkiemu jest Ten, który narodził się z Ducha i z Dziewicy. Przeto Ojciec Go począł, ponieważ Jego narodzenie cielesne nie zostało zaciemnione przez najmniejszą skazę właściwą współżyciu ludzkiemu"»0.

Godny podkreślenia jest wysiłek Ambrożego, by przy wyjaśnianiu prawd wiary i terminów teologicznych nie odcinać się od ówczesnej wiedzy medycznej i jej pojęć. W kontekście polemiki z poglądami nowacjańskimi, wskazywał np. na sposób poczęcia Jezusa jako przyczynę Jego wolności od grzechu. Cudowność tego poczęcia zapewniła ciału Chrystusa nieskalaność. W wypowiedzi Ambrożego, pomimo jego pozytywnej wizji małżeństwa, pobrzmiewa jednak nuta negatywnej wizji współżycia płciowego:

„[Chrystus] nie był* bowiem, jak wszyscy ludzie zrodzony z męskiego i żeńskiego złączenia, lecz narodzony z Ducha Świętego i Dziewicy; przyjął nieskalane ciało, którego nie tylko nie splamiły żadne skazy, lecz ani przy porodzeniu, ani przy poczęciu nic ujemnie nie działało na nie" ${ }^{\text {"81. }}$.

Ambroży, podejmując rozważania na temat fenomenów życia płodowego, odwoływał się często do historii biblijnych. Przykładowo, inspiracją do wzmianek o poruszaniu się dziecka w łonie matki był opis spotkania Maryi

${ }^{79}$ Por. Ambrosius, Expositio de Psalmo CXVIII 9, 19.

${ }^{80}$ Tenże, Explanatio Psalmorum XII (super Ps. XL 35), ed. L. F. Pizzolato, SAEMO 7, Milano - Roma 1980, 72: „«Propter innocentiam autem meam suscepisti me» (Ps. 40, 13). Quae autem susceptio significantur? Nam et alibi legimus: «Suscepisti me ex utero matris meae» (Ps. 138, 13). Ergo quia ab omni concretione generationis humanae mundus est natus qui de spiritu est natus et virgine, ideo eum pater suscepit, quia ortum eius nulla corporeae generationis concretio usitata fuscavit”, tłum. własne. Por. tenże, Explanatio Psalmorum (super Ps. XLVIII 5), gdzie Ambroży rozważa kim jest człowiek duchowy, a kim ziemski. Tego ostatniego definiuje jako spłodzonego $\mathrm{z}$ woli ciała i męża (ex carnis et viri voluptate generatus, SAEMO 7, 256).

${ }^{81}$ Tenże, De paenitentia I 3, 13, ed. G. Banterle, SAEMO 17, Milano - Roma 1982, 180: „Non enim sicut omnes homines ex viri erat* et feminae permixtione generatus, sed natus de Spiritu Sancto et Virgine inmaculatum corpus susceperat, quod non solum nulla vitia maculaverant, sed nec generationis aut conceptionis concretio iniuriosa fuscaverat", tłum. W. Szołdrski: Św. Ambroży, O pokucie, w: Św. Ambroży, Wybór pism, PSP 7, Warszawa 1971, 23-24 (thum. Szołdrski: *,jest”). 
z Elżbietą (Łk 1, 41-44) ${ }^{82}$ czy też zachowanie Rebeki (Rdz 25, 22) ${ }^{83}$. Z kolei rzeczywistość przebywania dziecka w łonie matki była dla Ambrożego podstawą do rozważań teologiczno-duchowych, w tym przypadku do rozwijania idei obecności Słowa w duszy ludzkiej.

Uwaga biskupa poświęcana okresowi błogosławionemu u kobiet miała z pewnością nie tylko cel katechetyczny, ale także duszpasterski. Biskup Mediolanu z pewnością troszczył się o przyszłe matki i rozumiał ich wyjątkowy trud i obciążenia. Starając się im pomóc, pouczał je o grożących niebezpieczeństwach i przekazywał ważne wskazania medyczne dla zdrowia i właściwego przebiegu okresu brzemienności ${ }^{84}$, której długość określał na dziewięć miesięcy ${ }^{85}$. W sposób zdecydowany przestrzegał przed aborcją ${ }^{86}$. Z jego słów przebija głęboka troska o rodzinę, zwłaszcza o wychowanie małżonków do podjęcia funkcji rodzicielskich.

Sam poród Ambroży opisywał takimi terminami i wyrażeniami, jak: $p a-$ rere, parturire, edere, generare, alvo excludere / emittere, ex utero fundere I nasci, partum absolvere / edere. Zdawał sobie sprawę, że zrodzenie potomka to dla kobiety kluczowy, a jednocześnie bardzo trudny moment. Na wyobrażenia Ambrożego o przejmujących bólach porodowych ${ }^{87}$ wpłynęły z pewnością nie tylko doświadczenia rodzących, ale także teksty biblijne, jak np. Rdz 3, 16 i Rz 8, 22. Dlatego m.in. Ambroży napominał akuszerki, by z pełnym oddaniem pomagały kobietom wydającym na świat dzieci ${ }^{88}$. Wzmiankował też pewne szczegóły ich pracy, np. obserwowanie znaków życia i płci noworod$\mathrm{ka}^{89}$. Zwracając się natomiast do synów i córek, zobowiązywał ich do trwałej wdzięczności wobec matek, które długo znosiły trudy brzemienności, potem przeżywały bóle rodzenia, a wreszcie wykarmiły ich własnym mlekiem:

${ }^{82}$ Por. tenże, Expositio Evangelii secundum Lucam I 33; tenże, De Isaac vel anima VI 53.

${ }^{83}$ Por. tenże, De Isaac vel anima IV 18.

${ }^{84}$ Ambroży zalecał np. abstynencję seksualną w okresie brzemienności. Teologiczno-moralne podstawy takiego wskazania, uzasadniał m.in. przykładem zaczerpniętym ze świata natury, a mianowicie zachowaniem zwierząt, które ,skoro poczują, iż są zapłodnione i przyjęły nasienie w organ płciowy, już nie spółkują" (Expositio Evangelii secundum Lucam I 44, SAEMO 11, 140, PSP 16, 46). Zalecenie abstynencji, a przynajmniej wydatnego ograniczenia współżycia seksualnego dla dobra płodu, było obecne w starożytnej literaturze medycznej.

${ }^{85}$ Por. tamże Expositio Evangelii secundum Lucam X 27.

${ }^{86}$ Por. tenże, Exameron V 8, 18, 58. Na temat aborcji w pismach wczesnochrześcijańskich zob. A. Muszala, Embrion ludzki, s. 402-471; M. Starowieyski, Aborcja i życie nienarodzonych w starożytności chrześcijańskiej, WST 22 (2009) fasc. 1, 117-147.

${ }^{87}$ Por. Ambrosius, De Abraham II 9, 63; tenże, De Helia et ieiunio XXI 80; tenże, Epistula VIII 56, 12.

${ }^{88}$ Por. tenże, Epistula VIII 56, 10.

${ }^{89}$ Por. tenże, Exameron IV 6, 4, 14. Kontekstem wypowiedzi Ambrożego jest polemika z astrologią. Podważa on możliwość ułożenia wiarygodnego horoskopu, jeśli jego podstawą ma być dokładna chwila narodzin. Tej bowiem żaden astrolog precyzyjnie nie zna, bo musi się opierać na relacjach położnej. 
„Choćbyś matce dawał pożywienie, to jednak nie wynagrodziłeś jej za te boleści, za te męki, jakie dla ciebie wycierpiała; nie wynagrodziłeś za to poświęcenie się, z jakim cię nosiła; nie wynagrodziłeś za tę delikatną miłość, z jaką twym ustom podawała swą pierś do ssania; nie wynagrodziłeś za głód, jaki dla ciebie znosiła, nie chcąc jeść nic takiego, co by na mleko mogło szkodliwie oddziałać; dla ciebie pościła, dla ciebie jadła, dla ciebie nie brała tego pożywienia, na które chęć miała, dla ciebie spożywała to, czego nie pragnęła, dla ciebie czuwała, dla ciebie płakała, a ty dopuszczasz do tego, iż ona cierpi biedę?" ${ }^{90}$.

Wysuwając taki ideał, wzorowany w dużej mierze na postaci matki siedmiu braci machabejskich (por. 2Mch 7, 27), Ambroży akcentował pewne walory moralne, a jednocześnie realizował cele duszpasterskie i edukacyjne. Szczegółowe wyliczenie elementów składających się na etos matki spełniało dwojaką rolę. $Z$ jednej strony wzmacniało szacunek do niej, z drugiej zaś skłaniało ją samą do odpowiednich zachowań wobec męża i dzieci. Warto w tym kontekście zauważyć zachętę do karmienia własnych niemowląt piersią, co w czasach Ambrożego nie było ani oczywiste, ani powszechne ${ }^{91}$.

Ojcowie Kościoła byli synami epok, w których żyli. Ich poglądy dotyczące ludzkiej płodności i rozrodczości odzwierciedlają ówczesne przekonania fizjologiczne i medyczne. W dzisiejszym rozwiniętym naukowo i technicznie świecie mogą wywołać zrozumiały uśmiech. Warto jednak podkreślić ich pragnienie i wysiłek, by przekazać spójną wizję antropologiczną łączącą dane biblijne i prawdy teologiczne z przekonaniami filozoficznymi i naukowymi. Z pism Metodego z Olimpu przebija głęboko pozytywna wizja ludzkiej seksualności i płodności, zdecydowana obrona godności dziecka poczętego oraz szacunek dla roli kobiety w procesie prokreacji. Ambroży z Mediolanu, z kolei, nie tylko starał się wyjaśnić cudowność Wcielenia Chrystusa na tle natury ludzkiego poczęcia i zrodzenia, ale także pomóc kobietom w zrozumieniu własnej fizjologii i zadań związanych z macierzyństwem.

${ }^{90}$ Tenże, Expositio Evangelii secundum Lucam VIII 75, ed. G. Coppa, SAEMO 12, Milano Roma 1978, 346: „Et si paveris matrem, adhuc non reddidisti dolores, non reddidisti cruciatus, quos pro te passa est, non reddidisti obsequia, quibus te illa gestavit, non reddidisti alimenta, quae tribuit tenero pietatis adfectu immulgens labris tuis ubera, non reddidisti famem, quam pro te illa toleravit, ne quid quod tibi noxium esset ederet, ne quid quod lacti noceret hauriret. Tibi illa ieiunavit, tibi manducavit, tibi illa quem voluit cibum non accepit, tibi quem noluit cibum sumsit, tibi vigilavit, tibi flevit: et tu illam egere patieris?”, PSP 16, 384.

${ }^{91}$ Por. tenże, Exameron V 8, 18, 58. Pisarze rzymscy (np. Tacitus, Dialogus de oratoribus I 28) uznawali, że niechęć niektórych „szlachetnych” Rzymianek do karmienia piersią jest znakiem upadku obyczajów. 


\section{FEMALE PHYSIOLOGY AND HUMAN REPRODUCTION IN THE WRITINGS OF METHODIUS OF OLYMPUS AND AMBROSE OF MILAN}

\section{(Summary)}

Topics concerning women's physiology and reproduction appear relatively rarely in the reflections of the Fathers of the Church. Most often they perpetuated the beliefs of ancient medicine, benefitting from the appropriate terminology. The originality of their reflection lies in trying to use the "scientific" facts within theological considerations (eg the creation of mankind and the Incarnation of the Son of God) and moral ones (eg the value of sexuality, fertility and parenthood). The scope of this article includes analysis of selected texts of Methodius of Olympus and those of Ambrose of Milan. Both authors had a deep medical knowledge of the issues and their works contain interesting examples related to female reproductive physiology. They were protagonists of an ideal of virginity, but yet, they preserved a positive assessment of fertility and marriage. Worthy of particular emphasis, in the works of Methodius, is the defense of the dignity of every unborn child, whom God himself creates and animates in the womb. The basis of the considerations in Symposium was a passage from Genesis 2: 21-24, to which he gave allegorical meaning, defining human sexuality and procreation as the typology of the divine and ecclesiastical realities. In turn, Ambrose undertook issues such as conception, prenatal development and the birth of a child, in the context of the exceptional role of Mary in the history of salvation and in the Incarnation of the Son of God. Theological considerations were an excellent opportunity for him to express moral teaching and pastoral care, and to provide very practical and helpful, medical and educational tips for women.

Key words: reproduction, sexuality, physiology, embryo, Methodius of Olympus, Ambrose of Milan.

Słowa kluczowe: rozrodczość, seksualność, fizjologia, embrion, Metody z Olimpu, Ambroży z Mediolanu.

\section{BIBLIOGRAFIA}

\section{Źródła}

Aeschylus, Eumenides, ed. P. Mazon, w: Eschyle, Opera, t. 2, Paris 1961, 132-171, tłum.

S. Srebrny: Ajschylos, Eumenidy, w: Ajschylos, Tragedie, Warszawa 1954, 441-486. Ambrosius, De Abraham, ed. F. Gori, SAEMO 2/II, Milano - Roma 1984.

Ambrosius, De apologiae prophetae David, ed. F. Lucidi, SAEMO 5, Milano - Roma 1981, 53-141.

Ambrosius, De Cain et Abel, ed. P. Siniscalco, SAEMO 2/I, Milano - Roma 1984, 176-305. Ambrosius, De Helia et ieiunio, ed. F. Gori, SAEMO 6, Milano - Roma 1985, 43-127.

Ambrosius, De Iacob et vita beata, ed. C. Moreschini, SAEMO 3, Milano - Roma 1982, 227-333. 
Ambrosius, De institutione virginis, ed. F. Gori, SAEMO 14/II, Milano - Roma 1989, 109-195.

Ambrosius, De Isaac vel anima, ed. C. Moreschini, SAEMO 3, Milano - Roma 1982, 31-125.

Ambrosius, De Noe, ed. P. Siniscalco, SAEMO 2/I, Milano - Roma 1984, 345-519.

Ambrosius, De paenitentia, ed. G. Banterle, SAEMO 17, Milano - Roma 1982, 171-283, tłum. W. Szołdrski: Św. Ambroży, O pokucie, w: Św. Ambroży, Wybór pism, PSP 7, Warszawa 1971, 19-88.

Ambrosius, De viduis, ed. F. Gori, SAEMO 14/I, Milano - Roma 1989, 243-319.

Ambrosius, Epistulae, ed. G. Benterle, SAEMO 19-21, Milano - Roma 1988.

Ambrosius, Exameron, ed. G. Benterle, SAEMO 1, Milano - Roma 1979.

Ambrosius, Exhortatio virginitatis, ed. F. Gori, SAEMO 14/II, Milano - Roma 1989, 197-271.

Ambrosius, Explanatio Psalmorum, ed. L. F. Pizzolato, SAEMO 7-8, Milano - Roma 1980.

Ambrosius, Expositio Evangelii secundum Lucam, ed. G. Coppa, SAEMO 11-12, Milano - Roma 1978, tłum. W. Szołdrski: Św. Ambroży, Wykład Ewangelii według św. Łukasza, PSP 16, Warszawa 1977.

Ambrosius, Expositio de Psalmo CXVIII, ed. L. F. Pizzolato, SAEMO 9-10, Milano Roma 1987.

Aristides, Apologia, ed. B. Pouderon - M.-J. Pierre, SCh 470, Paris 2003.

Aristoteles, De generatione animalium, éd. P. Louis, Collection des Universités de France. Série Grecque 152, Paris 2002, thum. P. Siwek: Arystoteles, O rodzeniu się zwierzat, Warszawa 1979.

Aristoteles, Historia animalium, éd. P. Louis, Collection des Universités de France. Série Grecque 164, Paris 2002, tłum. P. Siwek: Arystoteles, Zoologia, Warszawa 1982.

Clemens Alexandrinus, Paedagogus II, éd. H.-I. Marrou, SCh 108, Paris 1965.

Clemens Alexandrinus, Stromateis, ed. O. Stählin, GCS 15, Berlin 1906.

Eusebius, Praeparatio evangelica, éd. É. Des Places, SCh 338, Paris 1987.

Galenus, De semine, ed. Ph. De Lacy, Corpus Medicorum Graecorum V/3, 1, Berlin 1995.

Gregorius Nazianzenus, Carmen I 2, 29, PG 37, 884-908.

Hieronymus, In Hiezechielem, ed. F. Glorie, CCL 75, Turnhout 1964.

Hippocrates, De genitura, ed. R. Joly, Corpus Medicorum Graecorum I/2, 4, Berlin 2003. Ignatius Antiochenus, Ad Ephesios, éd. T. Camelot, SCh 10bis, Paris 1958, 66-93.

Ignatius Antiochenus, Ad Smyrnaeos, éd. T. Camelot, SCh 10bis, Paris 1958, 154-169.

JoAnnes Chrysostomus, De non iterando coniugio, éd. G.H. Ettlinger - B. Grillet, SCh 138, Paris 1968, 160-201.

JoAnnes Chrysostomus, In epistulam ad Ephesios hom. 20, PG 62, 135-150.

JoAnnes Chrysostomus, In epistulam I ad Corinthios hom. 23, PG 61, 275-285.

Justinus, Apologia I, éd. Ch. Munier, SCh 507, Paris 2006, 125-317.

Methodius, De lepra, ed. G.N. Bonwetsch, GCS 27, Leipzig 1917, 449-474.

Methodius, De resurrectione, ed. G.N. Bonwetsch, GCS 27, Leipzig 1917, 219-424.

Methodius, Symposium, éd. H.A. Musurillo - V.H. Debidour, SCh 95, Paris 1963, tłum. S. Kalinkowski: Metody z Olimpu, Uczta, w: Pierwsze pisma greckie o dziewictwie, ŹM 16, Tyniec - Kraków 1997, 127-253.

Petronius Arbiter, Satyricon, éd. A. Ernout, Paris 1950.

Philo Alexandrinus, Legum allegoriae, éd. C. Mondésert, Oeuvres de Philon d'Alexandrie 21, Paris 1962.

Plato, Timaeus, ed. R. G. Bury, LCL 9, London 1981, 16-253. 
Ps.-Iustinus, De resurrectione, ed. A. D’Anna, Pseudo-Giustino: Sulla resurrezione. Discorso cristiano del II secolo, Brescia 2001.

Stoicorum veterum fragmenta, ed. I. Ab Arnim, vol. 1, Stutgardiae 1964.

TAcitus, Dialogus de oratoribus, éd. H. Bornecque - H. Goelzer, Paris 1936.

Teophilus, Ad Autolicum, éd. G. Bardy, SCh 20, Paris 1948.

Tertullianus, De carne Christi, éd. J.P. Mahé, SCh 216, Paris 1975.

Opracowania

ANDRÉ J., Le vocabulaire latin de l'anatomie, Paris 1991.

Cilliers L., Vindicianus' Gynaecia and theories on generation and embryology from the Babylonians up to Graeco-Roman times, „Studies in Ancient Medicine” 27 (2004) 343-367.

Congourdeau M.-H., L'embryon et son âme dans les sources grecques, Paris 2007.

Enchiridion Vaticanum, t. 13, Bologna 1995.

Gourevitch D., Le mal d'être femme. La femme et la médecine dans la Rome antique, Paris 1984.

KInG H., Hippocrates' Woman. Reading the female body in Ancient Greece, London New York 1998.

La donna nel pensiero cristiano antico, ed. U. Mattioli, Genova 1992.

Laurence P., La faiblesse féminine chez les Pères de l'Eglise, w: Les Perès de l'Eglise face à la science médicale de leur temps. Actes du troisième colloque d'études patristiques (Paris, 9-11 septembre 2004), éd. V. Boudon-Millot - B. Pouderon, Théologie historique 117 , Paris 2005, 351-377.

Mazzucco C., Matrimonio e verginità nei Padri tra IV e V secolo: prospettive femminili, w: La donna nel pensiero cristiano antico, ed. U. Mattioli, Genova 1992, 119-153.

Muszala A., Embrion ludzki w starożytnej refleksji teologicznej, Kraków 2009.

Passarella R., Aspetti di medicina ginecologica e pediatrica nell'opera di Ambrogio, $\mathrm{w}$ : La cultura scientifico-naturalistica nei Padri della Chiesa (I-V sec.): XXXV Incontro di studiosi dell'antichità cristiana (4-6 maggio 2006), SEA 101, Roma 2007, 579-595.

Passarella R., Conoscenze mediche ambrosiane, ovvero la medicina nei Padri della Chiesa: questioni di metodo, „Acme” 57 (2004) fasc. 2, 69-91.

Pricoco S., Introduzione, w: L'eros difficile. Amore e sessualità nell'antico cristianesimo, ed. S. Pricoco, Armarium 9, Soveria Mannelli 1998, 9-11.

Prinzivalli E. , Desiderio di generazione e generazione del desiderio. Metodio di Olimpo e le polemiche sull'eros fra III e IV secolo, w: L'eros difficile. Amore e sessualità nell'antico cristianesimo, ed. S. Pricoco, Armarium 9, Soveria Mannelli 1998, 39-66.

Prinzivalli E., Donna e generazione nei Padri della Chiesa, w: La donna nel pensiero cristiano antico, ed. U. Mattioli, Genova 1992, 79-94.

Simonetti M., Presentazione, w: La donna nel pensiero cristiano antico, ed. U. Mattioli, Genova 1992, 7-10.

STAROWIEYSKI M., Aborcja i życie nienarodzonych w starożytności chrześcijańskiej, WST 22 (2009) fasc. 1, 117-147.

Tosato A., Processo generativo e sangue nell'antichità, w: Sangue e antropologia nella letteratura cristiana (Roma, 29 novembre - 4 dicembre 1982), ed. F. Vattioni, vol. 2, Roma 1983, 643-696. 